\title{
Impacts of macroalgal spores on the dynamics of adult macroalgae in a eutrophic estuary: High versus low hydrodynamic seasons and long-term simulations for global warming scenarios
}

\author{
Irene Martins*, Aránzazu Marcotegui, João Carlos Marques \\ IMAR - Institute of Marine Research, Coimbra Interdisciplinary Centre, Department of Zoology, University of Coimbra, 3004-517 Coimbra, Portugal
}

\begin{abstract}
A model describing macroalgal early life stages and adult dynamics was used to quantify the effects of non-adult forms on the productivity of adult macroalgae in a eutrophic estuary. Predictions indicate that during years with mild winters and low rainfall, spring blooms will occur at the expense of the growth and reproduction of overwintering adults and without the contribution of the spore bank. In these circumstances, there is a positive correlation between the intensity of the blooms and the biomass of overwintering adults until a maximum threshold value. On the contrary, in years with high rainfall and low or inexistent biomass of overwintering adults, the onset of adult's growth depends on the biomass of viable dormant spores, the growing season occurs later and adult productivity is very limited. Long-term predictions for climate change scenarios suggest that, in general, global warming will have adverse affects on Ulva intestinalis productivity, with the adults being more affected than the early life stages.
\end{abstract}

(C) 2008 Elsevier Ltd. All rights reserved.

Keywords: Ulva intestinalis; Spores; Overwintering adults; Model; Global warming

\section{Introduction}

Green macroalgae belonging to Chlorophyta (e.g. Ulva, Chaetomorpha) have been identified as one of the most abundant group of the so-called "bloom" forming algae in coastal areas worldwide (e.g. Valiela et al., 1997; Raffaelli et al., 1998; Schramm, 1999; Cardoso et al., 2004). Due to their higher surface to volume (SA:V) ratios compared to rooted macrophytes, opportunistic green macroalgae have higher maximum uptake rates and lower half-saturation constants for nutrients, associated with a higher affinity for nitrogen (Hein et al., 1995). As a consequence, under nutrient surplus, opportunistic macroalgae tend to grow faster than primary producers with a more conservative

\footnotetext{
${ }^{*}$ Corresponding author. Tel.: +351 239 855760; fax: +351 239823603. E-mail address: imartins@ci.uc.pt (I. Martins).
}

growing strategy (Pedersen and Borum, 1996). This type of mechanism often causes light limitation conditions for slower growing primary producers and, if such conditions persist, their standing stocks can be significantly decreased (e.g. Grall and Chauvoud, 2002; Raven and Taylor, 2003), which often has adverse impacts in the species richness and structure stability of the system (e.g. Norkko et al., 2000; Cardoso et al., 2004). In the last decades, a significant amount of work has examined adult green macroalgae populations, mostly due to their negative impacts in coastal areas worldwide (e.g. Boyer and Fong, 2005; Villares and Carballeira, 2003; Astill and Lavery, 2001). On the contrary, relatively fewer works have studied the processes affecting macroalgal early life stages (e.g. Worm and Lotze, 2006; Sousa et al., 2007). Macroalgal initial life stages are represented by several microscopic forms according to the adult's reproduction strategy. For example, Ulva intestinalis has different forms of reproduction: vegetative, asexual and sexual. Vegetative reproduction consists in 
separation from a parent plant of a vegetative component that latter develops into a new individual. Asexual reproduction occurs with an isomorphic alternation of haploid (gametophytes) and diploid (sporophyte) phases, which release biflagellate and motile gametes and quadriflagellate zoospores respectively; vegetative cells from zoospores and gametes can develop parthenogenetically. Sexual reproduction is anisogamic and involves fusion of male/female gametes, producing a zygote $(2 \mathrm{n})$ which growths into a sporophyte thallus. The zoospores from this thallus settle and germinate into male/female gametophytes (Fletcher, 1989; Poole and Raven, 1997).

The initial life forms of macroalgae can undergo a dormant stage represented by microscopic spores. Chapman (1986) defined the term "banks of microscopic forms" describing them as a combination of settled propagules, micro-recruits and microscopic life stages. These forms constitute an important overwintering mechanism in temperate ecosystems since they can promote algal recruitment in the following growth season (Schories, 1995; Lotze et al., 1999). Moreover, experimental evidence suggests that recruitment processes and factors affecting early life stages can determine the development and the dominance patterns of macroalgal blooms (Lotze and Worm, 2000). Although previous studies have suggested that spore survival may affect the growth of adult macroalgae (Schories, 1995; Lotze et al., 1999; Lotze and Worm, 2000; Worm et al., 2001), to our knowledge there are no works that have used a quantitative approach to this matter. Nevertheless, numerical models able to capture macroalgal microscopic-, juvenile- and adult-dynamics are suitable tools to address these subjects.

\section{Objectives}

The main objective of the present work was to use a macroalgal productivity model, describing both non-adult and adult dynamics, to quantify the contribution of algal early life stages (microscopic forms and juveniles $<10 \mathrm{~cm}$ length) on adult productivity in years with distinct climate features. Based on a relatively long-term data series, the model was developed for $U$. intestinalis population at the Mondego estuary (western coast of Portugal). Furthermore, the model was also used to make long-term predictions of macroalgal productivity under scenarios of climate change caused by global warming. Observations suggest that global warming may have already triggered abrupt climate changes resulting in an altered probability of drought, large floods, tropical storm landfall and monsoon rainfall (Overpeck and Cole, 2006). In accordance with this, the model was used to make predictions for climate change scenarios as expected for temperate regions, namely, intensive rainfall, prolonged drought associated with temperature increase and sea-level rise.

\section{Material and methods}

\subsection{Model conceptualization}

A model able to predict the total productivity of $U$. intestinalis on the south arm of the Mondego estuary (western coast of Portugal) (Fig. 1) was previously used to assess the impacts of total macroalgal biomass, carbon $(\mathrm{C})-$, nitrogen $(\mathrm{N})$ - and phosphorus (P)-loadings into the estuary and the adjacent coastal area (Martins et al.,

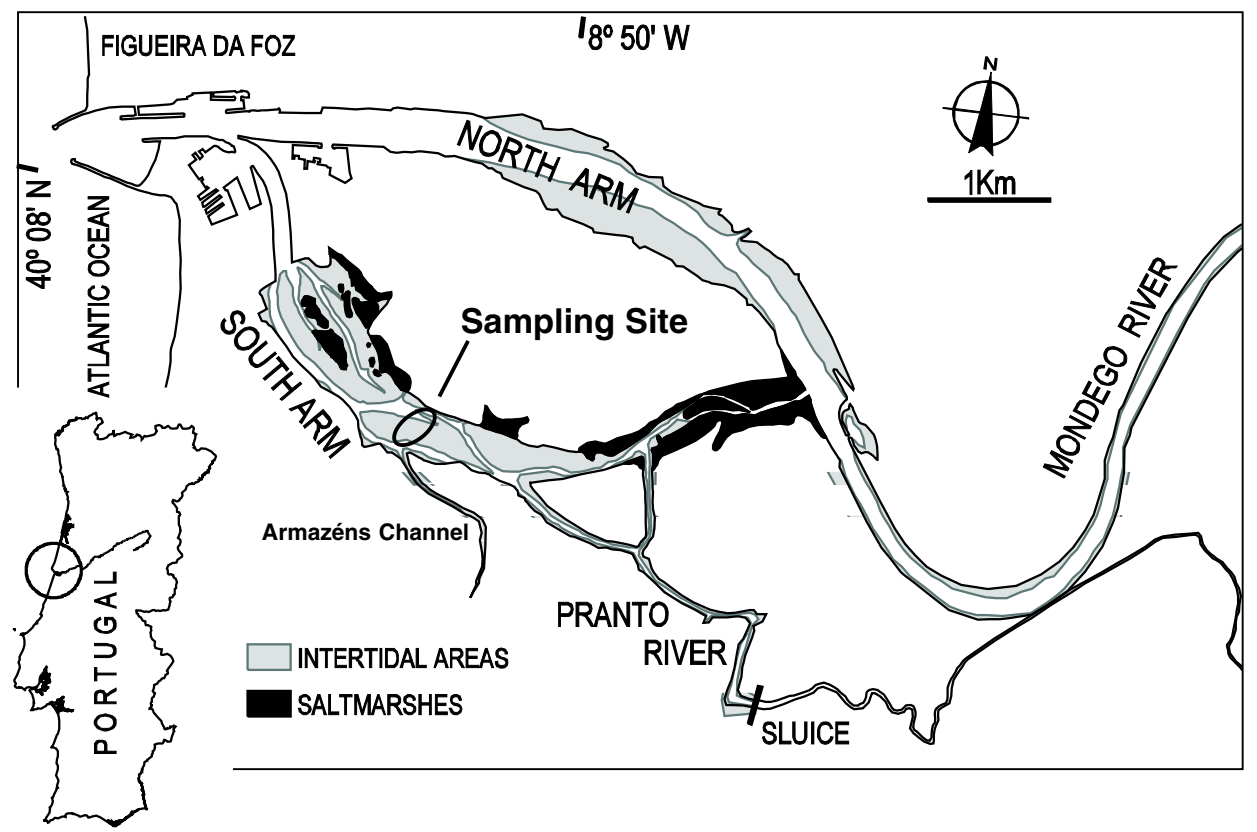

Fig. 1. The Mondego estuary with location of the sampling site used to collect data for the model's basic run. 


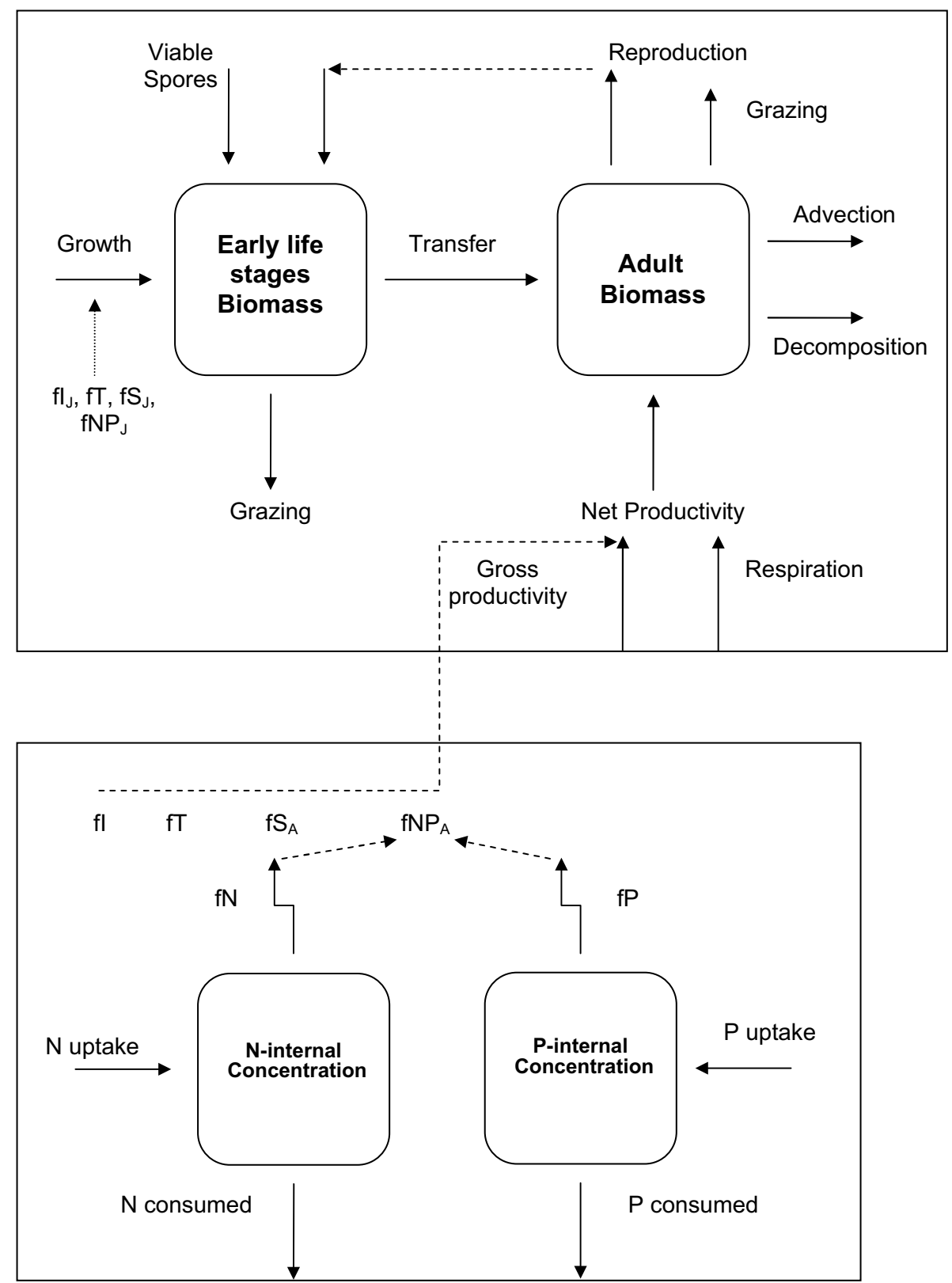

Fig. 2. Simplified conceptual diagram of the sub-model of macroalgal early life stages in connection with the sub-model of adult macroalgae developed by Martins et al. (2007).

2007). For a more detailed description of the Mondego estuary, see Martins et al. (2001), Lillebø et al. (2005), Neto et al. (2008). In the present work, the same model with a more detailed description of macroalgal early life stage dynamics is used to assess and quantify the effects of algal spores and juveniles on adult dynamics (Fig. 2).

We assumed that macroalgal early life stages include attached microscopic forms and macroscopic forms with $<10 \mathrm{~cm}$ length (juveniles). All $U$. intestinalis individuals with length $\geqslant 10 \mathrm{~cm}$ were considered as adults. The equations used to describe early life stage dynamics are described in detail in the next section. For details on the sub-models of $U$. intestinalis adults, light and tidal variations see Table 1 and Martins et al. (2007).

\subsection{Biomass variation of macroalgal early life stages}

The biomass variation of macroalgal early life stages was described by

$\frac{\mathrm{d} J}{\mathrm{~d} t}=R_{A}+D+G_{J}-Z_{J}-T_{A}$ 
Table 1

Main equations governing $U$. intestinalis adult-, light- and tidal-variation in the model

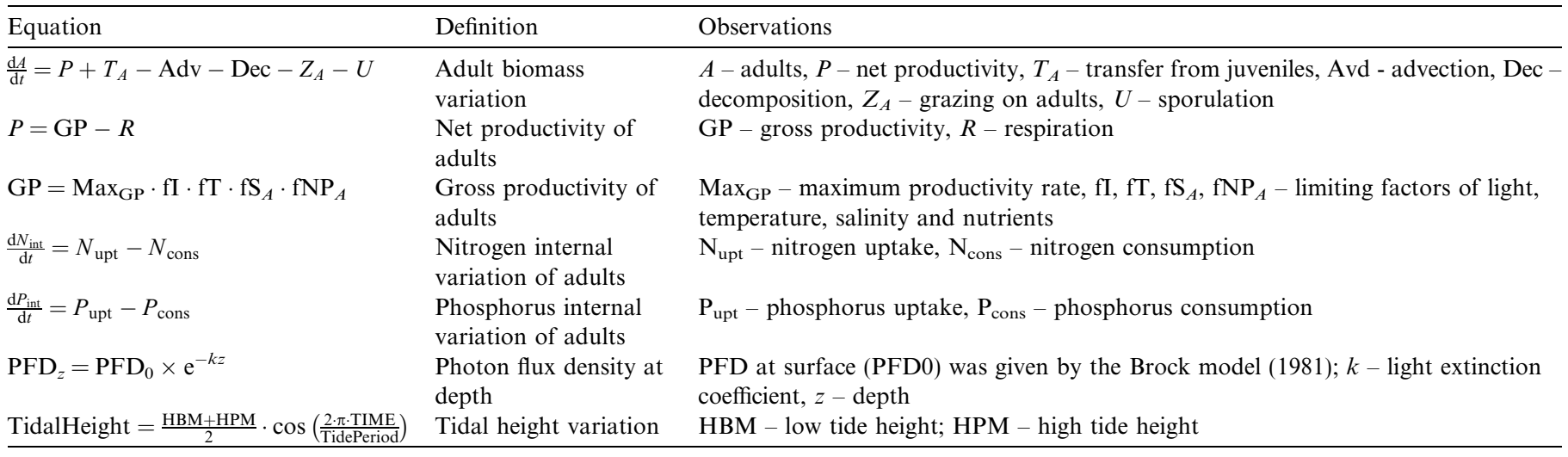

For details, see Martins et al. (2007).

where $J$ is the biomass of macroalgal early life stages, $R_{A}$ the adult's reproduction, $D$ the viable dormant spores, $G_{J}$ the growth, $Z_{J}$ the grazing by macroinvertebrates, $T_{A}$ the transfer to adults and $t$ is the time.
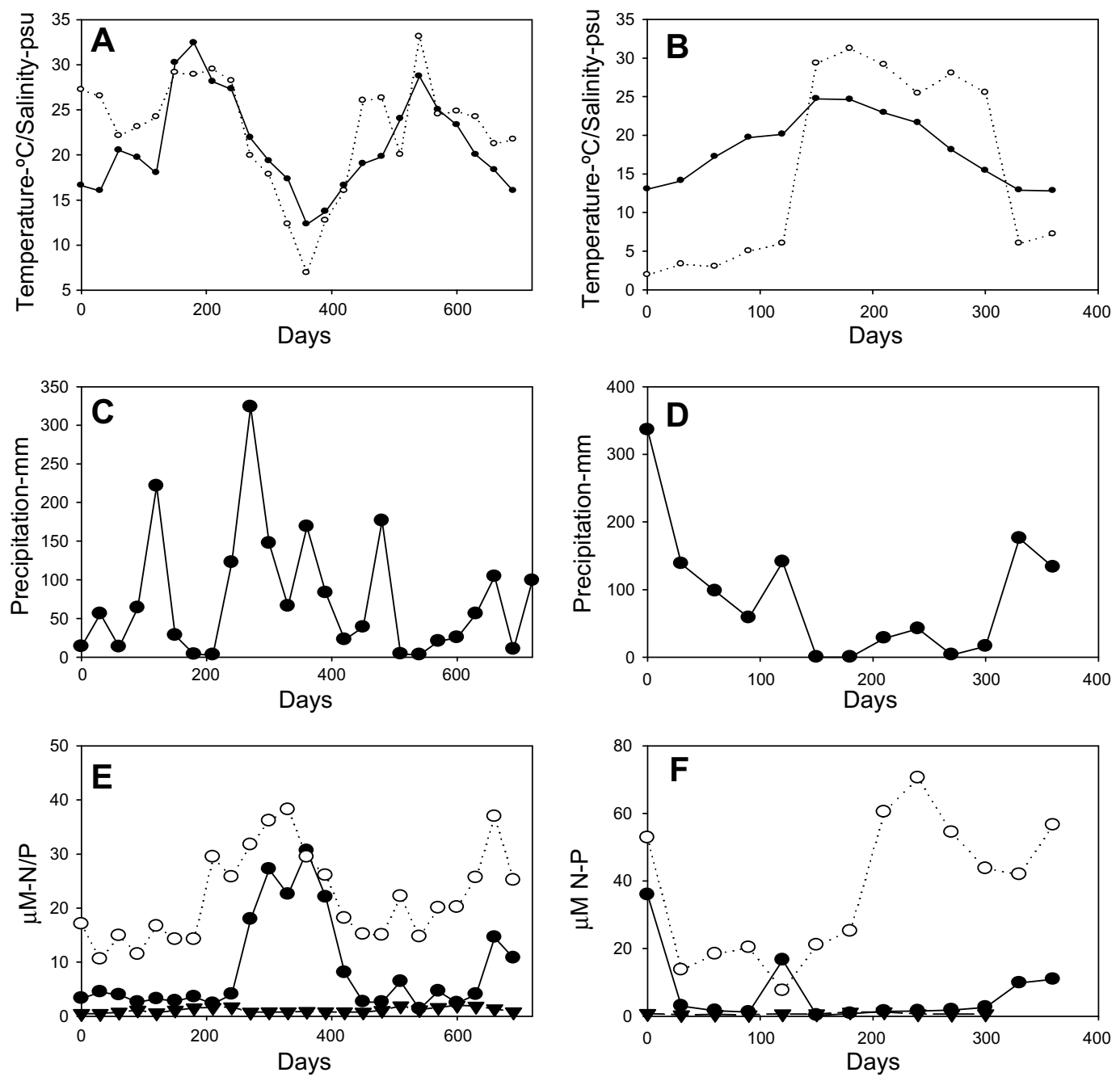

Fig. 3. Variation of external conditions in 1993-1994 (basic run): (A) temperature (--) and salinity (-O-), (C) precipitation, (E) N-NH 4 (-O-), N-NO $\left(-\bullet_{-}\right), \mathrm{P}_{-} \mathrm{PO}_{4}(-\boldsymbol{\nabla}-)$ and during an unfavourable year: (B) temperature (--) and salinity (-O-), (D) precipitation and $(\mathrm{F}) \mathrm{N}-\mathrm{NH}_{4}(-\mathrm{O}-), \mathrm{N}-\mathrm{NO}_{3}\left(-\bullet_{-}\right)$, $\mathrm{P}-\mathrm{PO}_{4}(-\boldsymbol{\nabla}-)$. 


\subsubsection{New recruits resulting from reproduction of adult macroalgae}

Adult macroalgae may allocate a significant amount of their biomass to the formation of zoospores and gametes, especially, during warmer months (Niesenbaum, 1988). For this reason reproduction was considered temperature dependent and the contribution of adult's reproduction to the production of new recruits $\left(R_{A}\right)$ was described as

$R_{A}=A \cdot \gamma \cdot R_{20} \cdot \theta^{(T-20)}$

where $A$ is the adult's biomass, $R_{20}$ the adult's reproduction rate at $20^{\circ} \mathrm{C}, T$ the temperature, $\theta$ the empirical coefficient and $\gamma$ is the recruit's survival rate.

\subsubsection{The contribution of dormant spores}

As previously mentioned, $U$. intestinalis has a dormant life stage represented by microscopic spores, which can survive for some time in the sediments under adverse conditions (Schories and Reise, 1993). If external conditions are favourable, viable microscopic spores attach to substrata and germinate. In the model, these processes were represented by

$D=B_{D} \cdot \lambda_{\max } \cdot \mathrm{fT} \cdot \mathrm{fI}_{J} \cdot \mathrm{fS}_{J} \cdot \mathrm{fNP}_{J}$

where $D$ is the viable spore's biomass, $B_{D}$ the bank spore's biomass, $\lambda_{\max }$ the maximum germination rate and $\mathrm{fT}, \mathrm{fI}_{J}$, $\mathrm{fS}_{J}$ and $\mathrm{fNP}_{J}$ are the temperature, light salinity and nutri- ent limitation factors, respectively (described in the next section). The bank spore's biomass $\left(B_{D}\right)$ used in the model was based on in situ quantifications (Sousa et al., unpublished) followed by calibration corresponding to $10 \mathrm{mg} \mathrm{C} \mathrm{m}^{-2}$.

\subsubsection{The growth of early life forms}

The growth of Ulva's early life forms was described by

$G_{J}=B_{J} \cdot \mu_{\max } \cdot \mathrm{fT} \cdot \mathrm{fI}_{J} \cdot \mathrm{fS}_{J} \cdot \mathrm{fNP}_{J}$

where $B_{J}$ is the biomass of Ulva's early life forms, $\mu_{\max }$ the maximum growth rate and $\mathrm{fT}, \mathrm{fI}_{J}, \mathrm{fS}_{J}$ and $\mathrm{fNP}_{J}$ are the temperature, light salinity and nutrient limitation factors, respectively.

3.2.3.1. The effect of temperature. Experimental evidence suggests that $U$. intestinalis requires a temperature within the range $10-15{ }^{\circ} \mathrm{C}$ for germination (Lotze et al., 1999), although the maximum growth rate of $U$. intestinalis adults tends to occur at higher temperatures (Poole and Raven, 1997). This kind of variation is indicative of an optimumtype curve, which can be described by

$\mathrm{fT}=\exp \left[-2.3 \cdot\left(\frac{T-T_{\mathrm{opt}}}{T_{x}-T_{\mathrm{opt}}}\right)^{2}\right]$

Table 2

Definitions, values and source of the parameters used in the macroalgal early life stages sub-model

\begin{tabular}{|c|c|c|c|c|c|}
\hline Symbol & Description & Units & $\begin{array}{l}\text { Used } \\
\text { value }\end{array}$ & $\begin{array}{l}\text { Lit. } \\
\text { range }\end{array}$ & Source \\
\hline$R_{20}$ & Adult's reproduction rate at $20^{\circ} \mathrm{C}$ & $\mathrm{d}^{-1}$ & 0.01 & Max. 0.6 & Niesenbaum (1988) \\
\hline$\theta$ & Empirical coefficient & - & 1.047 & $1.01-1.2$ & EPA (1985) \\
\hline$G_{J \max }$ & Maximum germination rate & $\mathrm{d}^{-1}$ & 0.8 & $0.4-1.0$ & Hoffmann and Camus (1989) \\
\hline$\gamma$ & Recruit's survival rate & $d^{-1}$ & 0.1 & - & Empirical and calibration \\
\hline$T_{\text {opt }}$ & $\begin{array}{l}\text { Optimum temperature for germination } \\
\text { and growth }\end{array}$ & ${ }^{\circ} \mathrm{C}$ & 22 & $15-30$ & Based on values for adults - Poole and Raven (1997) \\
\hline$T_{\min }$ & $\begin{array}{l}\text { Lower temperature for germination } \\
\text { and growth }\end{array}$ & ${ }^{\circ} \mathrm{C}$ & 10 & - & Based on values for adults - Poole and Raven (1997) \\
\hline Is & Optimum light intensity for photosynthesis & $\mu \mathrm{mol} \mathrm{E} \mathrm{m}{ }^{-2} \mathrm{~s}^{-1}$ & 250 & $125-250$ & Kim and Lee (1996) \\
\hline$S_{\text {opt }}$ & $\begin{array}{l}\text { Optimum salinity for germination and } \\
\text { growth }\end{array}$ & psu & 35 & - & Sousa et al. (2007) \\
\hline$N_{\min }$ & Minimum internal quota for nitrogen & $\mu \mathrm{mol} \mathrm{N}(\mathrm{mg} \mathrm{C})^{-1}$ & 5.7 & & Arhonditsis and Brett (2005) \\
\hline$P_{\min }$ & Minimum internal quota for phosphorus & $\mu \mathrm{mol} \mathrm{P}(\mathrm{mg} \mathrm{C})^{-1}$ & 0.258 & & Arhonditsis and Brett (2005) \\
\hline$N_{\text {umax }}$ & Maximum nitrogen uptake rate & $\mu \mathrm{mol} \mathrm{N}\left(\mathrm{mg} \mathrm{C}^{-1} \mathrm{~d}^{-1}\right.$ & 11.42 & - & Arhonditsis and Brett (2005) \\
\hline$P_{\text {umax }}$ & Maximum phosphorus uptake rate & $\mu \mathrm{mol} \mathrm{P}\left(\mathrm{mg} \mathrm{C}^{-1} \mathrm{~d}^{-1}\right.$ & 0.29 & & Arhonditsis and Brett (2005) \\
\hline KN & Half-saturation constant for nitrogen & $\mu \mathrm{mol} \mathrm{N}{ }^{-1}$ & 3.214 & & Arhonditsis and Brett (2005) \\
\hline $\mathrm{KP}$ & Half-saturation constant for phosphorus & $\mu \mathrm{mol} \mathrm{P} 1^{-1}$ & 0.322 & & Arhonditsis and Brett (2005) \\
\hline$Z_{J}$ & Grazing rate on young algae & $d^{-1}$ & 0.23 & $\begin{array}{l}0.06- \\
0.14\end{array}$ & Lotze and Worm (2000) \\
\hline$T_{\mathrm{opt} Z}$ & Optimum temperature for grazers & ${ }^{\circ} \mathrm{C}$ & 22 & - & Based on local macroinvertebrate biomass variation \\
\hline$T_{\max Z}$ & Upper temperature for grazers & ${ }^{\circ} \mathrm{C}$ & 45 & - & Based on local macroinvertebrate biomass variation \\
\hline$T_{\min } Z$ & Lower temperature for grazers & ${ }^{\circ} \mathrm{C}$ & 10 & - & Based on local macroinvertebrate biomass variation \\
\hline
\end{tabular}


$T_{x}=T_{\min }$ for $T \leqslant T_{\mathrm{opt}}$ and $T_{x}=T_{\max }$ for $T>T_{\mathrm{opt}}$, where $T_{\text {opt }}$ is the optimum temperature for germination and initial growth, $T_{\min }$ the lower temperature limit below which germination and initial growth ceases and $T_{\max }$ is the upper temperature limit above which germination and initial growth ceases.

3.2.3.2. The effect of light. Germlings of benthic algae seem to have lower light requirements than adults (e.g. Kim and Lee, 1996 and references therein), which may be related with the increase in the proportion of non-photosynthetic internal tissues during growth. Values reported in the literature indicate maximum photon flux densities between 125 and $250 \mu \mathrm{E} \mathrm{m}^{-2} \mathrm{~s}^{-1}$ (Kim and Lee, 1996) and $600 \mu \mathrm{E} \mathrm{m}^{-2} \mathrm{~s}^{-1}$ (Shellem and Josselyn, 1982; Beer and Shragge, 1987) for the production of algal juveniles and adults, respectively.

On the other hand because adults of $U$. intestinalis are photoinhibited by increased photon flux densities (Häder et al., 1999), a photoinhibition-type curve is frequently used to describe the light limitation factor of the adults (e.g. Bendoricchio et al., 1993; Martins and Marques, 2002). Although we found no specific references for Ulva sp. spores, photoinhibition of spores of other algae species has been observed under certain conditions, such as high irradiation intensities (Stibal et al., 2007) or UV-radiation (e.g. Huovinen et al., 2000; Wiencke et al., 2000; Bischof et al., 2006). Based on this, the effect of light on the growth of $U$. intestinalis early life stages was described by

$\mathrm{fI}_{J}=\frac{I}{\mathrm{Is}} \cdot \mathrm{e}^{\left(1-\frac{I}{\mathrm{Is}}\right)}$

where $I$ is the photon flux density $\left(\mu \mathrm{E} \mathrm{m}^{-2} \mathrm{~s}^{-1}\right)$ and Is is the optimum photon flux density for $U$. intestinalis early life forms $\left(\mu \mathrm{E} \mathrm{m}^{-2} \mathrm{~s}^{-1}\right)$.

3.2.3.3. The effect of salinity. Macroalgal recruitment tends to be lower at low temperatures and salinities (Flavier and Ziyigmark, 1993). In the case of $U$. intestinalis, spore
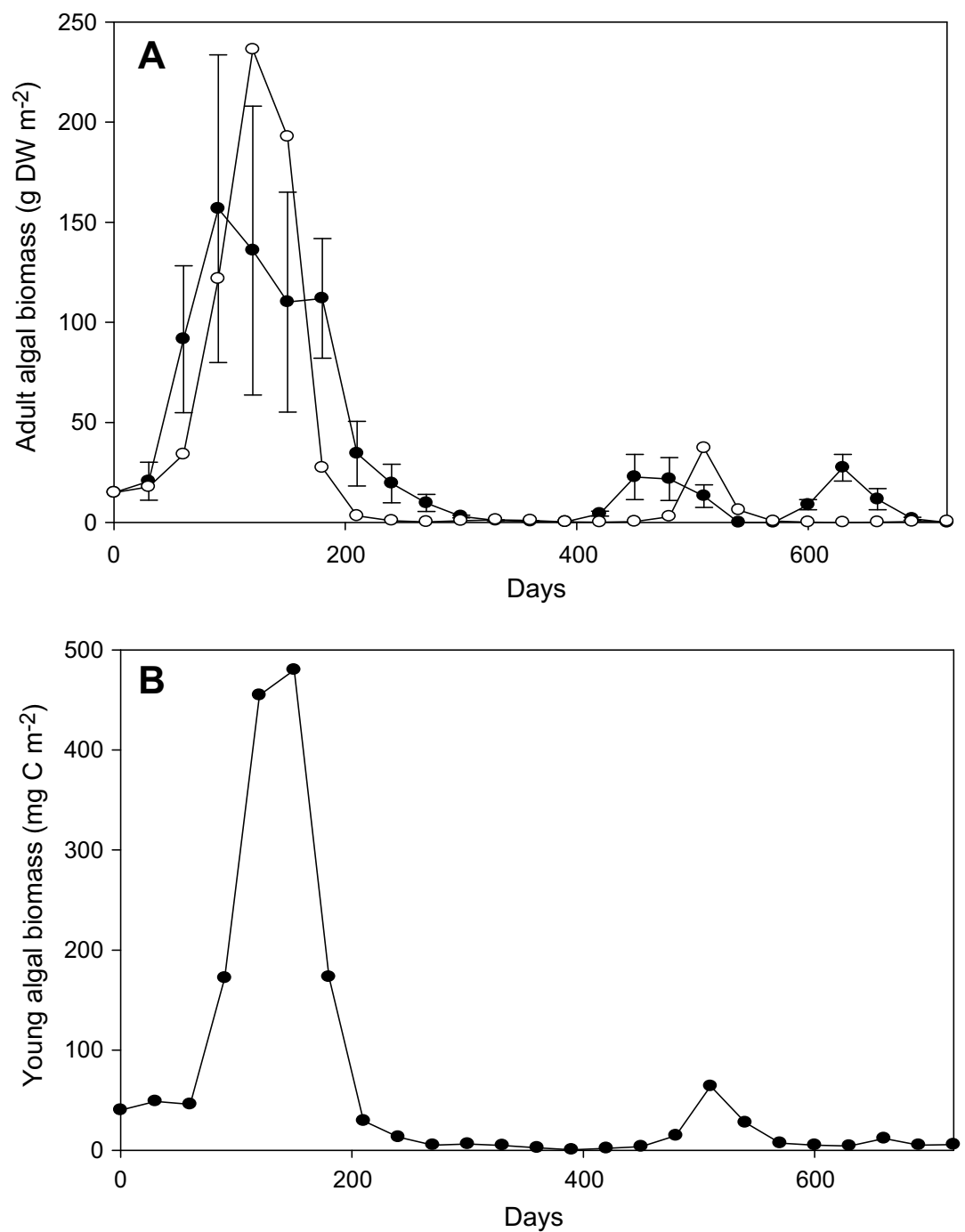

Fig. 4. Predicted (-O-) and observed (- - ) biomass variation \pm standard error of $U$. intestinalis adults (A) and predicted biomass of $U$. intestinalis early life stages (B) between 1993 and 1994 (basic run). 
germination is enhanced at $35 \mathrm{psu}$ and decreases with decreasing salinities (Sousa et al., 2007). Taking this into consideration, the effect of salinity on macroalgal early life stages was described as

$\mathrm{fS}_{J}=1-\left(\frac{S-S \mathrm{opt}}{\mathrm{Sx}-\mathrm{Sopt}}\right)^{m}$

$\mathrm{Sx}=S_{\min }$ and $m=2.5$ for $S<S_{\mathrm{opt}} \mathrm{Sx}=S_{\max }$ and $m=2$ for $S \geqslant S_{\text {opt }}$ where $S_{\text {opt }}$ is the optimum salinity for germination and initial growth, $S_{\min }$ the lower salinity limit below which germination and initial growth cease and $S_{\max }$ is the upper salinity limit above which germination and initial growth cease.

3.2.3.4. The effect of nutrients. The nutrient limitation factor was described accordingly with "Liebig's law of the minimum" (e.g. EPA, 1985). Additionally, as the uptake by phytoplankton, the nutrient uptake by macroalgal spores and juveniles was considered dependent on both external and internal nutrient concentrations (Arhonditsis and Brett, 2005):

$$
\begin{aligned}
& \mathrm{fNP}_{J}=\min \left\{\frac{N_{\mathrm{i}}-N_{\text {min }}}{N_{\text {max }}-N_{\min }}, \frac{P_{\mathrm{i}}-P_{\text {min }}}{P_{\max }-P_{\min }}\right\} \\
& \frac{\partial N_{\mathrm{i}}}{\partial t}=N_{\mathrm{u}} \times N_{\mathrm{r}}-G \cdot N_{\mathrm{i}}, \quad \frac{\partial P_{\mathrm{i}}}{\partial t}=P_{\mathrm{u}} \times P_{\mathrm{r}}-G \cdot P_{\mathrm{i}} \\
& N_{\mathrm{u}}=N_{\mathrm{u} \text { max }} \frac{N}{N+K N}, \quad P_{\mathrm{u}}=P_{\mathrm{u} \max } \frac{P}{P+\mathrm{KP}} \\
& N_{\mathrm{r}}=\frac{N_{\max }-N_{\mathrm{i}}}{N_{\max }-N_{\min }}, \quad P_{\mathrm{r}}=\frac{P_{\max }-P_{\mathrm{i}}}{P_{\max }-P_{\min }}
\end{aligned}
$$

where $N_{\mathrm{i}}$ is the internal nitrogen concentration, $P_{\mathrm{i}}$ the internal phosphorus concentration, $N_{\mathrm{umax}}$ the maximum uptake rate of nitrogen, $P_{\text {uma }}$ the maximum uptake rate of phosphorus, KN the nitrogen half-saturation constant, KP the phosphorus half-saturation constant, $N_{\min }$ the minimum internal nitrogen quota, $P_{\min }$ the minimum internal
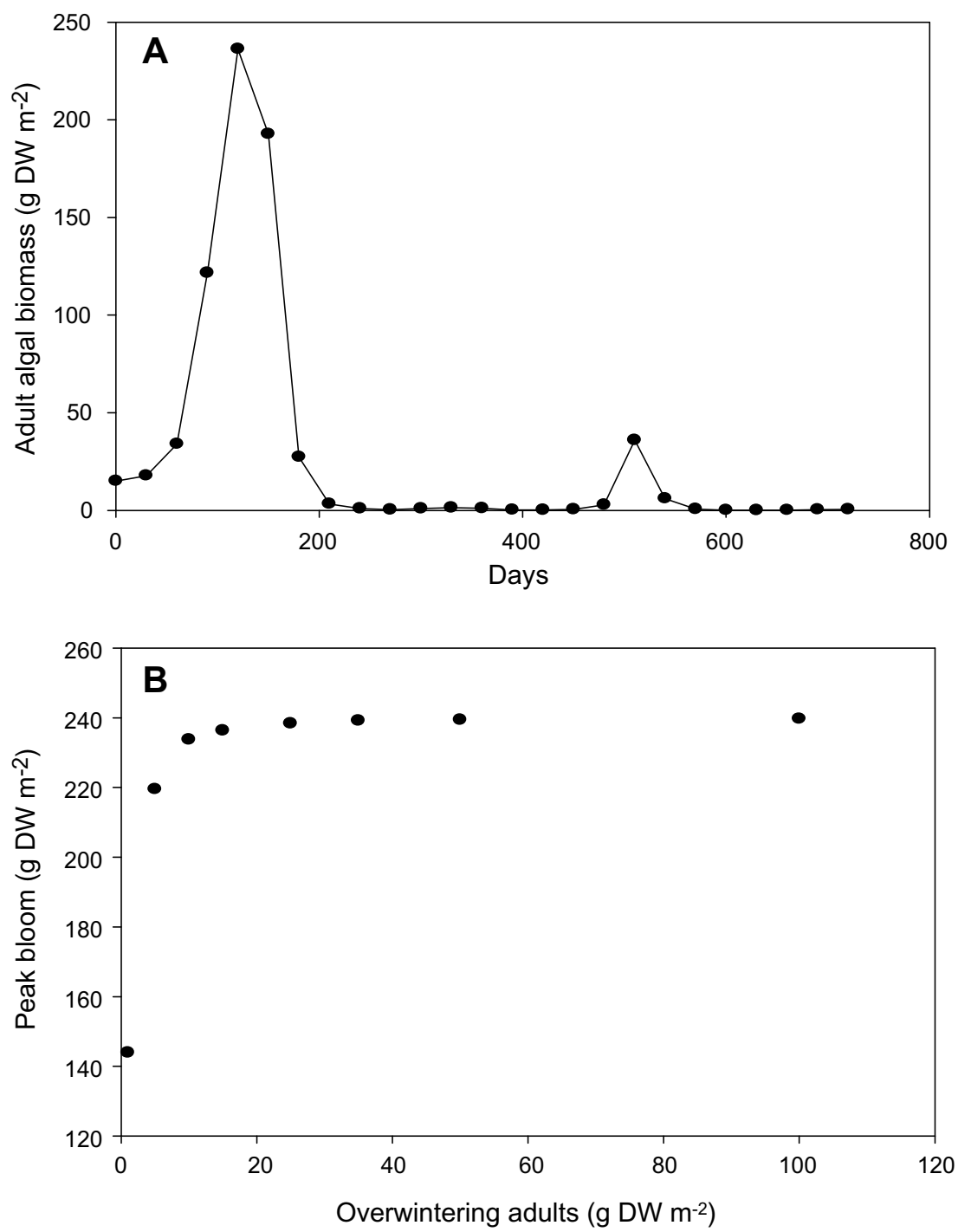

Fig. 5. Predicted biomass of $U$. intestinalis adults during a favourable period and without the contribution of spores (A). Relationship between the biomass of overwintering adults and the maximum adult biomass reached during the spring bloom (peak bloom) in a favourable year (B). 
phosphorus quota, $N_{\max }$ the maximum internal nitrogen quota, $P_{\max }$ the maximum internal phosphorus quota, $N$ the nitrogen external concentration and $P$ is the phosphorus external concentration.

\subsubsection{Grazing on macroalgal early life stages}

Herbivory is a process with very significant impacts on algal early life stages and has been reported as reducing algal juveniles at rates varying from 0.06 to $0.14 \mathrm{~d}^{-1}$ (Worm and Chapman, 1998; Lotze and Worm, 2000; Worm and Lotze, 2006). According to this, the effect of grazers was described as

$Z_{J}=B_{J} \cdot Z_{r} \cdot f\left(T_{Z_{J}}\right)$

where $B_{J}$ is the biomass of Ulva's early life forms, $Z_{r}$ the grazing rate on macroalgal early life stages and $f\left(T_{Z_{\mathrm{J}}}\right)$ is the temperature limiting factor of grazers.

\subsubsection{Transfer to adults}

The maximum growth rate of macroalgal early life forms can reach $0.8 \mathrm{~d}^{-1}$ (Hoffmann and Camus, 1989). On the other hand, on a laboratorial setup using limiting light conditions for macroalgal growth, the average growth of $U$. intestinalis spores at 20 and 35 psu was estimated as $0.25 \pm 0.11 \mathrm{~d}^{-1}$ (Sousa et al., 2007). Taking this range into consideration, it was assumed that microscopic forms take approximately 12 days to achieve the adult size $(10 \mathrm{~cm}$ length). The time lag between the microscopic and the adult phase was taken into consideration through the specific expression "DELAY", included in STELLA software. Through calibration, the amount of early life forms being transferred to adults per day was set at $1 \%$.

\subsection{Simulations}

The model's basic run includes temperature, salinity, nutrients (dissolved inorganic nitrogen and phosphorus)
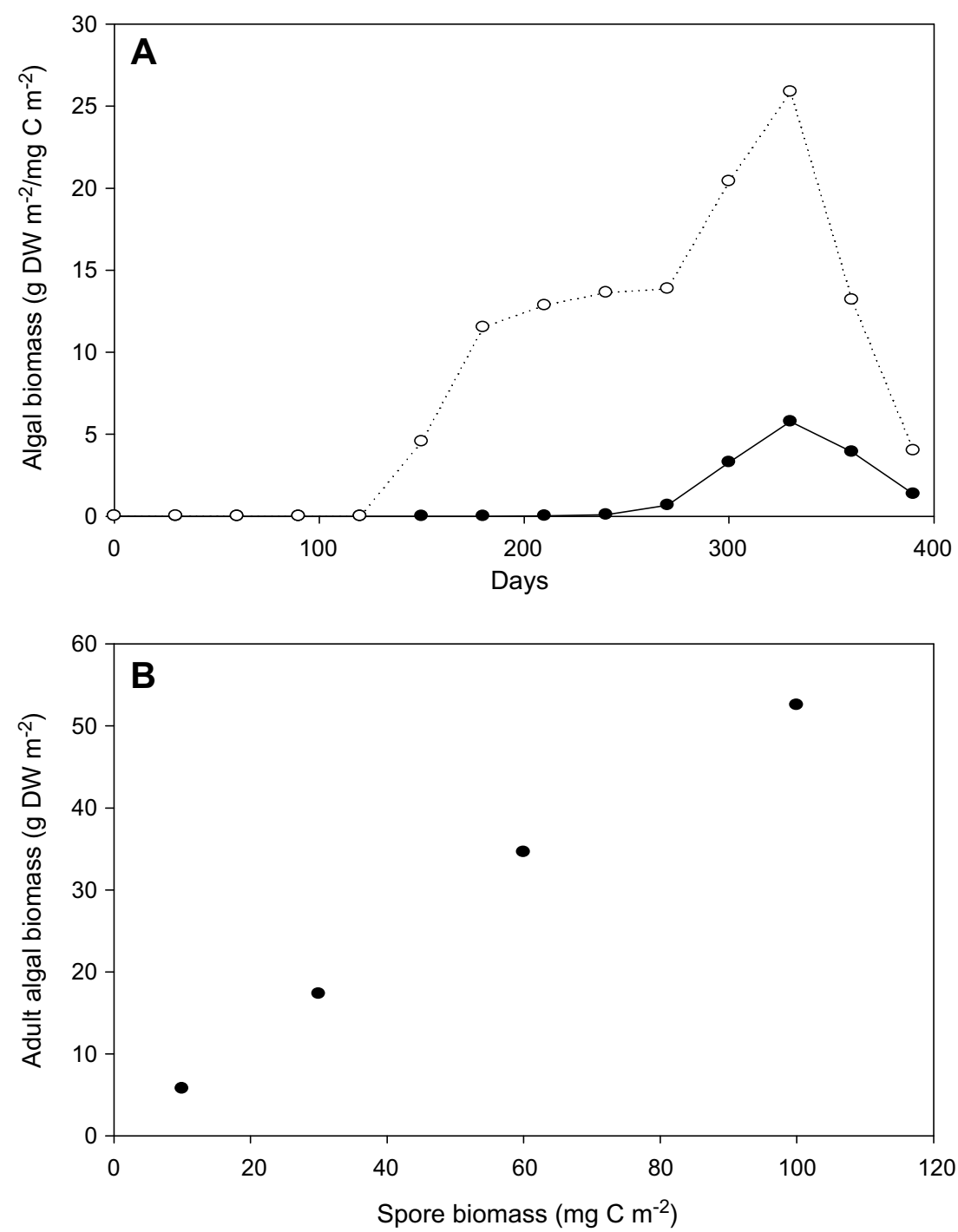

Fig. 6. Predicted biomass of $U$. intestinalis' adults (--) and early life stages (young) (-O-) under unfavourable conditions (A). Relationship between the biomass of spores stored in the spore's bank and the maximum adult biomass attained in an unfavourable year (B). 
and precipitation values corresponding to the variation observed in a sampling site located at the Mondego estuary, between January 1993 and January 1994 (Figs. 3A and B). According to the Assessment of Estuarine Trophic Status methodology (ASSETS - Bricker et al., 2003) related to the overall eutrophic condition (OEC), 1993 and 1994 were classified as high OEC and medium OEC, respectively (Martins et al., 2007) and, consequently, represent favourable conditions for macroalgal growth. On the contrary, 1996 was classified as low OEC (Martins et al., 2007). Therefore, in the present work, the variations of external conditions registered for 1996 were used to simulate the scenario of unfavourable conditions. Parameter def-

Table 3

Sensitivity analysis for a favourable and an unfavourable year

\begin{tabular}{|c|c|c|c|c|}
\hline \multirow[t]{2}{*}{ Parameters } & \multicolumn{2}{|c|}{ Favourable year } & \multicolumn{2}{|c|}{ Unfavourable year } \\
\hline & Adults & Juveniles & Adults & Juveniles \\
\hline$\overline{B_{\mathrm{D}}+}$ & 0 & 0.09 & 1 & 1 \\
\hline$B_{\mathrm{D}^{-}}$ & 0 & 0.09 & 1 & 1 \\
\hline$Z_{\mathrm{J}}+$ & -0.01 & -0.92 & -0.89 & -1.08 \\
\hline$Z_{\mathrm{J}}-$ & -0.25 & -13 & -7.32 & -35 \\
\hline$\lambda+$ & 0 & 0.09 & 1 & 1 \\
\hline$\lambda-$ & 0 & 0.1 & 1 & 1 \\
\hline$\mu+$ & 0.01 & 1.55 & 0.4 & 0.88 \\
\hline$\mu-$ & 0 & 0.52 & 0.24 & 0.44 \\
\hline $\mathrm{Adv}+$ & -0.2 & -0.15 & -0.47 & -0.13 \\
\hline $\mathrm{Adv}-$ & -0.53 & -0.47 & -0.64 & -0.17 \\
\hline$Z_{\mathrm{A}}+$ & -0.46 & -0.33 & -1.33 & -0.38 \\
\hline$Z_{\mathrm{A}^{-}}$ & -1.13 & -0.91 & -4.45 & -1.24 \\
\hline Dec + & -0.67 & -0.51 & -1.60 & -0.45 \\
\hline Dec - & -2.57 & -1.97 & -10.57 & -2.83 \\
\hline$R_{20}+$ & -0.32 & 0.53 & -0.98 & -0.12 \\
\hline$R_{20}-$ & -0.75 & 0.57 & -2.05 & 0.01 \\
\hline
\end{tabular}

$B_{\mathrm{D}}-$ biomass of dormant spores, $Z_{\mathrm{J}}-$ grazing rate on juveniles, $\lambda-$ germination rate, $\mu$ - growth rate, Adv - advection rate of adults, $Z_{\mathrm{A}}-$ grazing rate on adults, Dec - decomposition rate of adults, $U$ - reproduction rate. inition and values are shown in Table 2. In every run, the initial simulation time corresponds to January. Based on available data for the Mondego estuary (e.g. Lillebø et al., 2005; Sousa et al., 2007), state variable initial values in the basic run were set at $40 \mathrm{mg} \mathrm{C} \mathrm{m}^{-2}$ and $15 \mathrm{~g} \mathrm{DW}$ (dry weight) $\mathrm{m}^{-2}$, for algal juveniles and adults, respectively. For unfavourable conditions, the initial values of the state variables were set at $0 \mathrm{mg} \mathrm{C} \mathrm{m}^{-2}$ and $0.01 \mathrm{~g} \mathrm{DW} \mathrm{m}^{-2}$, for algal juveniles and adults, respectively, based on the assumption that - under these conditions - there are no overwintering adults or juveniles in January. Global warming scenarios were run with state variable's initial values equal to the basic run and corresponded to three different scenarios: (1) Intense rainfall during winters and springs followed by dry summers; (2) Prolonged drought with no increase on the average temperature and with a increase of $2{ }^{\circ} \mathrm{C}$ and $4{ }^{\circ} \mathrm{C}$ on the average water temperature; (3) Sea-level increase of $1 \mathrm{~m}$ per century according to ice sheet collapse predictions (Overpeck and Cole, 2006) associated to the expansion of ocean water (IPCC, 2007). For all runs, the initial simulation time corresponds to January and the DT is 30 days.

\subsection{Calibration, sensitivity and statistical analysis}

Parameter calibration was achieved by optimisation algorithms, followed by comparison of predicted and observed adult biomass variation between January 1993 and January 1994, to assess for model reliability. Model II regression was used to compare predicted and observed $U$. intestinalis biomass variation, whilst the significance of the regression was tested by ANOVA.

Sensitivity analysis was performed in accordance with Jørgensen (1994). To assess for the sensitivity of the state variables in different years, sensitivity analysis was performed under favourable and unfavourable external conditions.

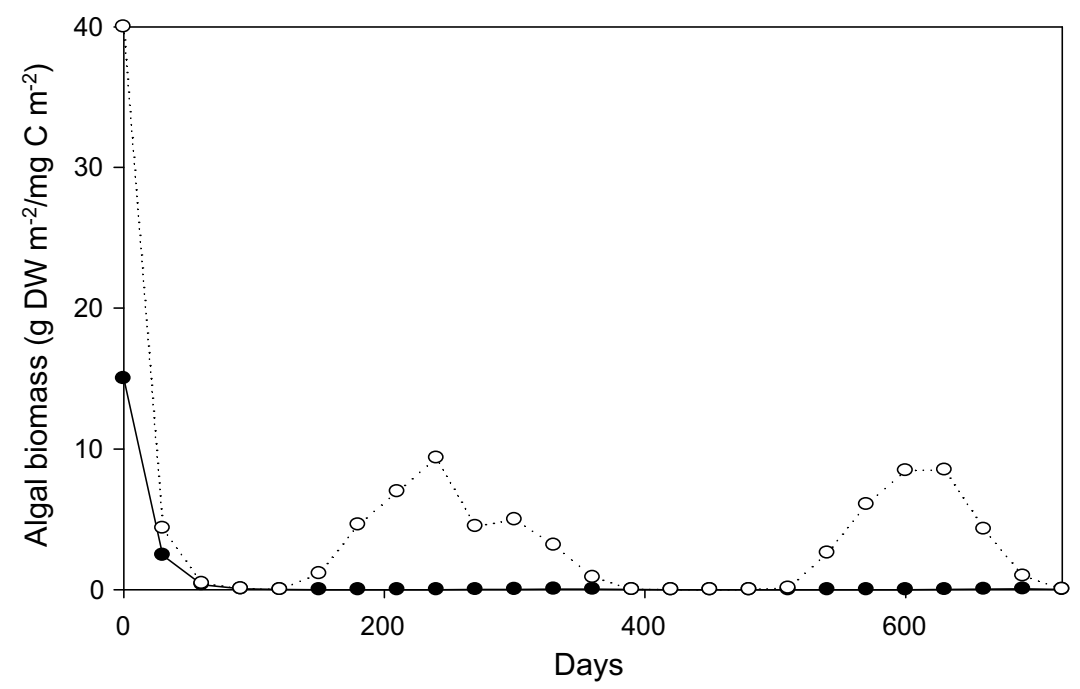

Fig. 7. Predicted biomass of $U$. intestinalis' adults (--) and early life stages (young) (-O-) during scenarios of intense rainfall. 


\section{Results}

In general, the predicted biomass of adult macroalgae follows the same variation as the observed biomass (Fig. 4A). The regression between the two sets of data is significant (ANOVA, $F_{1,22}=42, \quad P<0.001, \quad r^{2}=0.65$ ) and, thus, the model was considered valid to address the initial questions.

According to simulations, for 1993-1994, the biomass of young macroalgae follows the same pattern of variation as adult macroalgae, reaching a maximum value of $480 \mathrm{mg} \mathrm{C} \mathrm{m}^{-2}$ during spring of 1993 (Fig. 4B).

According to predictions, in years characterized by the occurrence of favourable external conditions during winter and spring, spring blooms will take place even without the contribution of the spore bank (Fig. 5A). Under favourable external conditions, a biomass of $1 \mathrm{~g} \mathrm{DW} \mathrm{m}^{-2}$ in winter can promote a spring bloom of $\sim 144 \mathrm{~g} \mathrm{DW} \mathrm{m}^{-2}$ in spring and the peak of the spring bloom increases linearly with the adult overwintering biomass until $5 \mathrm{~g} \mathrm{DW} \mathrm{m}^{-2}$
(Fig. 5B). Beyond this threshold, the peak bloom tends to stabilise for further increases of the adult overwintering biomass (Fig. 5B). On the contrary, during years presenting unfavourable conditions to algal growth, the total annual productivity of $U$. intestinalis also depends on the biomass accumulated as spores, particularly, if there are no overwintering adults or very few. In these circumstances, $U$. intestinalis exhibits a very low and later growth peak (Fig. 6A), which increases linearly with the biomass stored in the spore bank (Fig. 6B).

Results from the sensitivity analysis show that, as expected, adults and early life forms of $U$. intestinalis are more sensitive to parameter changes in unfavourable years compared to favourable ones. Particularly, grazing rates and decomposition are extremely sensitive parameters during unfavourable years (Table 3).

Simulations suggest that intense rainfall in winter and spring followed by dry summers have dramatic impacts on $U$. intestinalis populations, with the adults being more affected than the juveniles (Fig. 7).
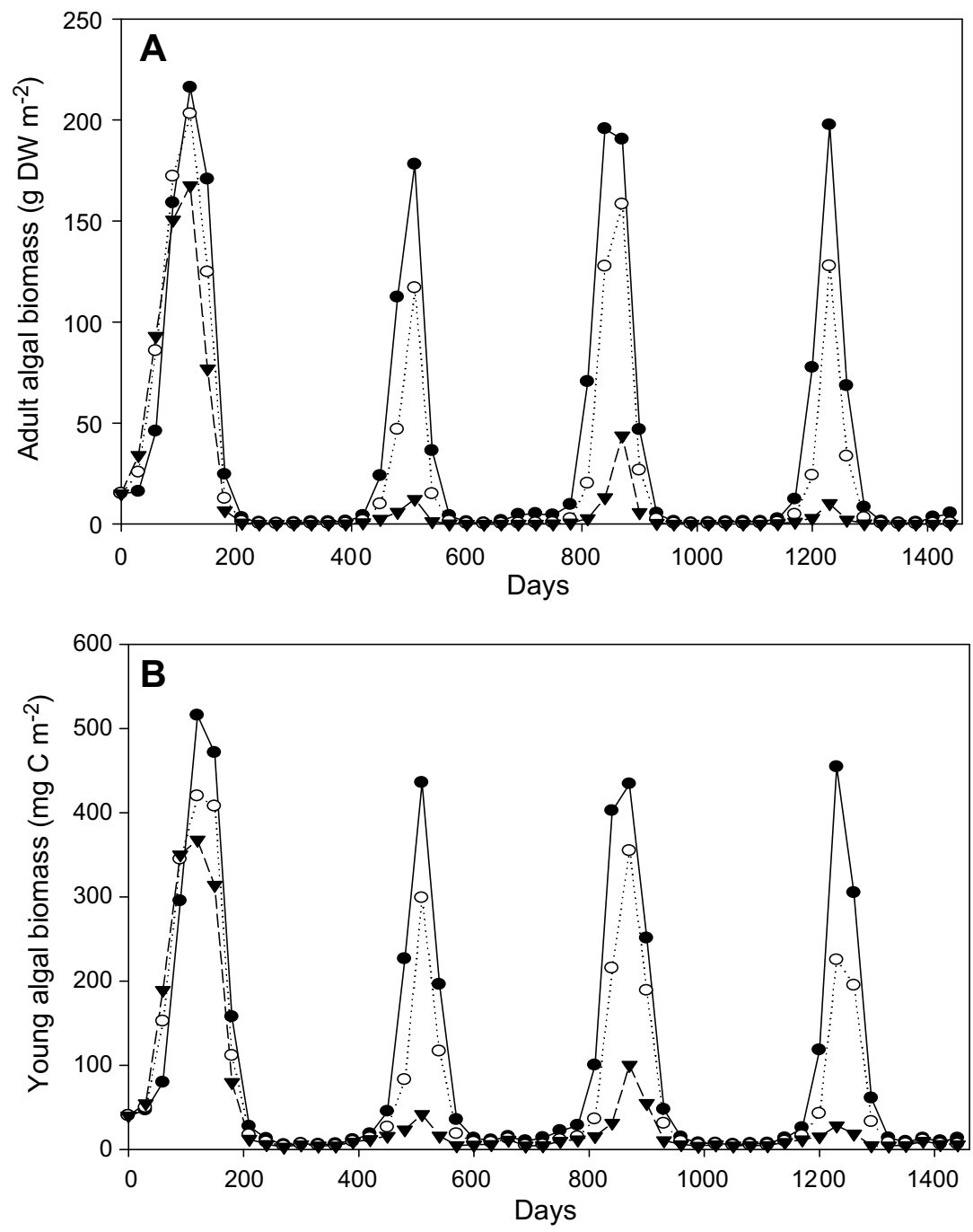

Fig. 8. Predicted biomass of $U$. intestinalis' adults (A) and early life forms (young) (B) for scenarios of prolonged drought without temperature increase $(--)$, with a $2{ }^{\circ} \mathrm{C}$ temperature increase $\left(-\mathrm{O}_{-}\right)$and a $4{ }^{\circ} \mathrm{C}$ temperature increase $\left(-\boldsymbol{\nabla}_{-}\right)$. 
The occurrence of dry winters and summers favours macroalgae populations as long as temperature values are kept similar to those observed in 1993-1994. However, long-term simulations of dry conditions associated to increases of the average temperature have negative impacts on $U$. intestinalis population. $U$. intestinalis populations located at the intertidal area, more precisely at $+1.8 \mathrm{~m}$, exhibit an average decrease of $\sim 30$ and $66 \%$ on productivity for increases of $2{ }^{\circ} \mathrm{C}$ and $4{ }^{\circ} \mathrm{C}$, respectively, compared to simulations with no temperature increase (Fig. 8).

Predictions for sea-level rise suggest that $U$. intestinalis will exhibit significant decreases on productivity, particularly, for bathymetries $\leqslant+2 \mathrm{~m}$. According to simulations for a sea level rise of $1 \mathrm{~m}, U$. intestinalis will not subsist at bathymetries $\leqslant+2 \mathrm{~m}$, whilst at a bathymetry of $+2.3 \mathrm{~m}$, U. intestinalis productivity decreases about $84 \%$ compared to the values quantified in 1993-1994 (Fig. 9). In this scenario, $U$. intestinalis will disappear from about $\sim 81 \%$ of the actual intertidal area (between $-0.9 \mathrm{~m}$ and
$+1.8 \mathrm{~m}$ ) but it will persist in $\sim 19 \%$ of the actual intertidal area corresponding to bathymetries ranging from $+1.9 \mathrm{~m}$ to $+2.3 \mathrm{~m}$ (Fig. 10). However, if sea level rise $(1 \mathrm{~m})$ is accompanied by an increase on the average water temperature, the productivity of $U$. intestinalis located at $+2.3 \mathrm{~m}$ tends to decrease with increasing temperatures (Fig. 11).

\section{Discussion}

The present results confirm previous studies which indicate that, even at eutrophied coastal areas, the growth of opportunistic macroalgae is highly variable and depends on several factors. Besides the abiotic parameters (e.g. precipitation, salinity, water current) identified as key-factors on the regulation of the inter-annual variation of $U$. intestinalis on the Mondego estuary (Martins et al., 2001), the present work suggests that biotic factors, namely, the amount of macroalgae spores can also play an important role on the yearly growth and productivity of opportunistic
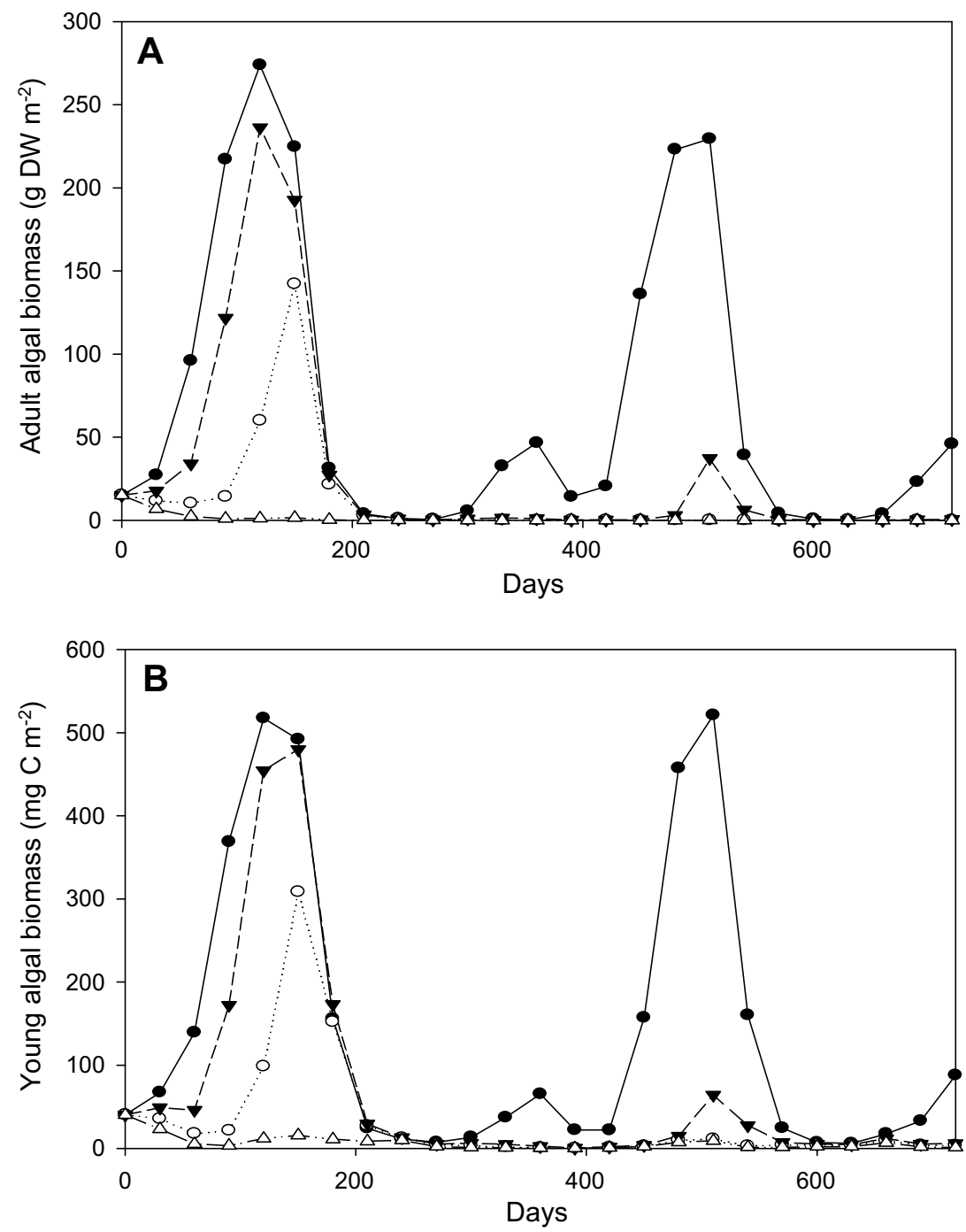

Fig. 9. Comparison of the biomass variation of $U$. intestinalis's adults (A) and early life forms (young) (B) between scenarios with and without sea level rise and at different bathymetries. $+2.3 \mathrm{~m}$ without sea level rise $\left(-\bullet_{-}\right),+1.8 \mathrm{~m}$ without sea level rise $\left(-\mathbf{\nabla}_{-}\right),+2.3 \mathrm{~m}$ with $1 \mathrm{~m}$ sea level rise $\left(-\bigcirc_{-}\right),+1.8 \mathrm{~m}$ with $1 \mathrm{~m}$ sea level rise $\left(-\Delta_{-}\right)$. 

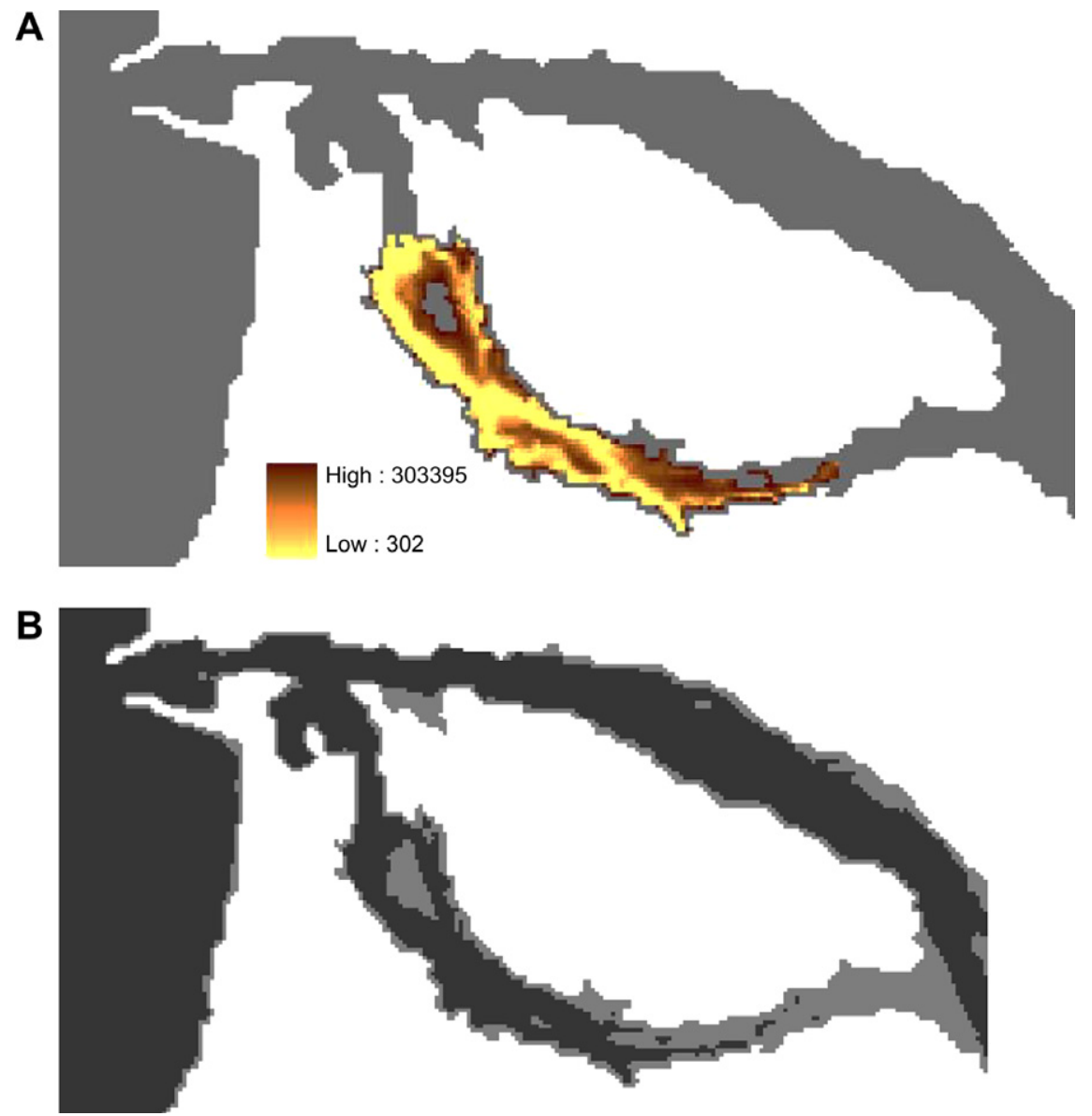

Fig. 10. Comparison between predictions of the bathymetric distribution of $U$. intestinalis adults in April 1993 (A): high $-304 \mathrm{~g} \mathrm{DW} \mathrm{m}^{-2}$, low $0.302 \mathrm{~g} \mathrm{DW} \mathrm{m}^{-2}$ and scenarios of sea level rise $(1 \mathrm{~m})(\mathrm{B})$ at the south channel of the Mondego estuary: dark grey - areas where $U$. intestinalis will not subsist, Light grey - areas where $U$. intestinalis can still grow (see text for explanation).

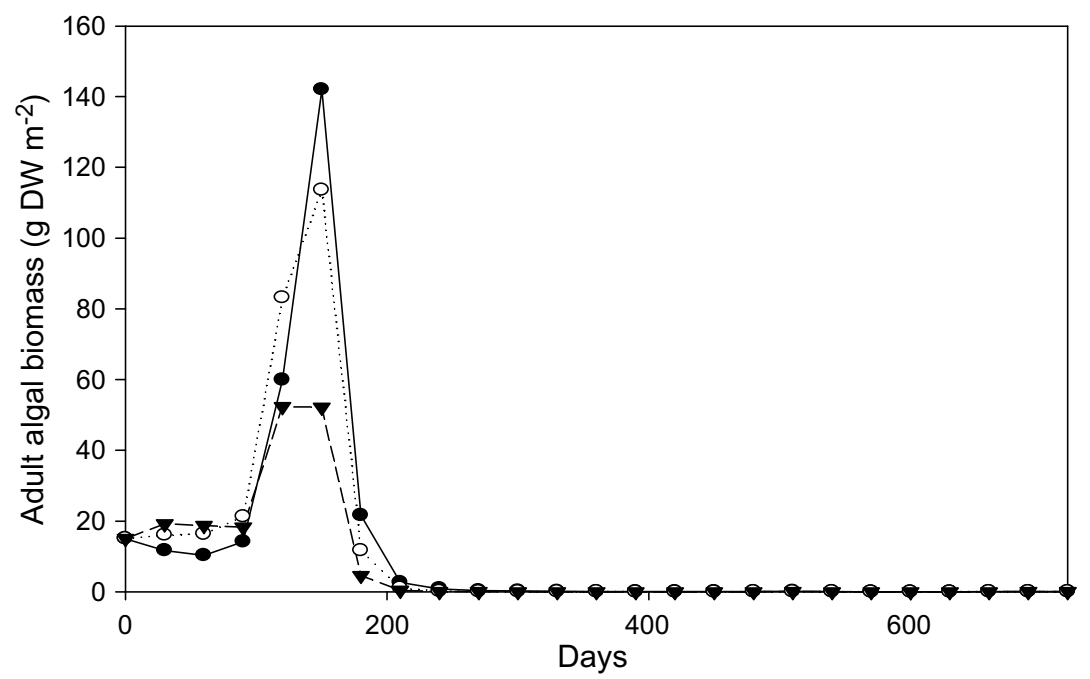

Fig. 11. Predicted biomass variation of $U$. intestinalis' adults at $+2.3 \mathrm{~m}$ for scenarios of sea level rise ( $1 \mathrm{~m})$ without temperature increase (- - ), with a $2{ }^{\circ} \mathrm{C}$ temperature increase (-O-) and a $4{ }^{\circ} \mathrm{C}$ temperature increase $\left(-\nabla_{-}\right)$.

algae. According to the present model, in unfavourable years - when adult macroalgae do not persist throughout winter or are present in very low amounts - the onset of
$U$. intestinalis growth occurs at the expense of microscopic spores. Furthermore, the growing season does not take place in spring but later on in the year (beginning of 
Table 4

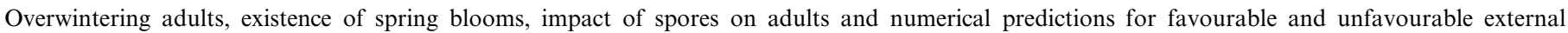
conditions

\begin{tabular}{|c|c|c|c|c|}
\hline External conditions & $\begin{array}{l}\text { Persistence of adults } \\
\text { during winter }\end{array}$ & Spring adult bloom & Impact of spores on adults & Numerical predictions \\
\hline $\begin{array}{l}\text { Favourable: low } \\
\text { hydrodynamics }\end{array}$ & Yes & Yes & Not significant & $\begin{array}{l}5 \mathrm{~g} \mathrm{DW} \mathrm{m}^{-2} \text { of adults } \\
\text { in January } \\
\downarrow \\
\sim 200 \mathrm{~g} \mathrm{DW} \mathrm{m}^{-2} \text { of } \\
\text { adults in May }\end{array}$ \\
\hline $\begin{array}{c}\text { Unfavourable: high } \\
\text { hydrodynamics }\end{array}$ & No & $\begin{array}{l}\text { No } \\
\text { The growing season takes place } \\
\text { later in the year }\end{array}$ & $\begin{array}{l}\text { Highly significant } \\
\text { The onset of adult growth depends on } \\
\text { microscopic spores }\end{array}$ & $\begin{array}{l}10 \mathrm{mg} \mathrm{C} \mathrm{m}^{-2} \text { of spores } \\
\downarrow \\
\sim 6 \mathrm{~g} \mathrm{DW} \mathrm{m}{ }^{-2} \text { of adults } \\
\text { in autumn }\end{array}$ \\
\hline
\end{tabular}

Favourable: low rainfall, high salinity, low currents, low light extinction; unfavourable: high rainfall, low salinity, high currents, high light extinction coefficients.

autumn) and adult productivity is very limited (Table 4). According to simulations, in these circumstances, adult macroalgal productivity increases linearly with the biomass of spores accumulated in the dormant bank, which is in accordance with previously reported experimental evidence (e.g. Santelices et al., 1995; Lotze et al., 1999). Thus, the present results indicate that, under unfavourable conditions, $U$. intestinalis productivity is strongly dependent on the biomass accumulated in the spore bank. Although little research has focused on the viability of macroalgal spores accumulated in the sediments, experimental evidence suggest that spores are still viable after remaining in the sediments for 10 months but their viability decreases over time (Schories, 1995). Taking this and the present results into consideration, it is reasonable to assume that, during unfavourable years, the productivity of adult macroalgae will also depend on the timing that optimal conditions take to arise. The latter these conditions occur, the less adult biomass will be accumulated in the system due to lower amounts of viable spores.

On the contrary, during favourable years - when external conditions allow the persistence of adults of $U$. intestinalis during winter - predictions suggest that spring growth can take place independently of the spore bank (Table 4) and that, in these circumstances, macroalgal productivity increases linearly with the biomass of overwintering adults until a certain threshold value is reached $\left(\sim 5 \mathrm{~g} \mathrm{DW} \mathrm{m}^{-2}\right)$. Above this threshold, the peak bloom stabilises which is related to light limitation conditions caused by self-shading. This process is accounted in the model (Martins et al., 2007).

Predictions for climate change scenarios suggest that $U$. intestinalis will be adversely affected by the occurrence of persistent and intense rainfall in the winter and spring, which is related with the adverse impacts that several external factors, such as low salinity, high light extinction coefficients, high $N: P$ ratios and high current velocities have on the growth of $U$. intestinalis early life stages (Sousa et al., 2007) and on the growth and transport of adults (Martins et al., 1999, 2001; Kamer and Fong, 2001; Neto et al., 2008). In this scenario, the highest sensitivity of adults compared to algal juveniles is related with the significant advection of adult macroalgae from the system, which occurs whenever high rainfall associated to significant freshwater discharges to the system take place (Neto et al., 2008). Due to their smaller size, attached spores and juveniles are not so vulnerable to drifting out of the system as adult macroalgae.

If drought periods are associated with water temperature increases, predictions indicate that, although less dramatically than in the former scenario, $U$. intestinalis will also decrease its productivity at the Mondego estuary. This is due to the effect of desiccation on young and adult macroalgae (e.g. Matta and Chapman, 1995), which is described and taken into account in the model (Martins et al., 2007). In accordance to most climate change scenarios which predict an increase in the average global temperature (IPCC, 2007), in the present work, we have only considered scenarios of temperature increase. However, the occurrence of climate feedbacks (positive or negative) may increase the complexity of temperature responses to global warming (EPA, <http://www.epa.gov/climatechange/science/futuretc.html $>$ ).

A sea level rise of $1 \mathrm{~m}$ - as expected to occur in one century if the ice sheet collapse predictions are confirmed (Overpeck and Cole, 2006) - will cause a significant decrease on $U$. intestinalis productivity at the Mondego estuary due to the general increase of depth and the consequent decrease of light reaching macroalgal surface. According to predictions, in this situation due to light limitation, $U$. intestinalis will disappear from $\sim 81 \%$ of the actual intertidal area (between $-0.9 \mathrm{~m}$ and $+1.8 \mathrm{~m}$ ) but it will persist in $\sim 19 \%$ of the actual intertidal area corresponding to bathymetries ranging from $+1.9 \mathrm{~m}$ to $+2.3 \mathrm{~m}$. However for simulations where sea level rise is accompanied by temperature increases, the productivity of $U$. intestinalis located at higher bathymetries will decrease with increasing temperatures, mostly, due to desiccation.

In general, the present results reflect the correct incorporation into the model of processes related to algal early life 
stages and adult dynamics and their dependency on external environmental conditions.

In conclusion, the present work corroborates the idea that hydrodynamics control macroalgae productivity at shallow mesotidal estuaries. During low hydrodynamic conditions, adults of $U$. intestinalis persist in the system throughout winter and, during spring, macroalgal blooms are likely to happen without the contribution of dormant spores. On the contrary, under high hydrodynamic conditions, adult macroalgae drift out the system and external conditions do not favour the growth of persistent individuals. As a consequence, macroalgae productivity will be extremely limited and strongly dependent on the biomass of dormant spores. Predictions for global warming scenarios suggest that, in general, $U$. intestinalis will be adversely affected due to light limitation, desiccation and advection. In certain scenarios, the productivity of $U$. intestinalis will be strongly dependent on the viability and growth of microscopic forms and juveniles since adults tend to be more sensitive to high hydrodynamics and sea level rise.

\section{Acknowledgements}

The present work was supported by The Portuguese Foundation for Science and Technology (FCT) through a post-doc grant to I. Martins (SFRH/BPD/5665/2001) and IMAR-CIC and the Project EFICAS (Effects of natural stress generated by freshwater discharges in the benthic invertebrate estuarine communities and its influence on the assessment of the benthic ecological status) (POCI/MAR/ 61324/2004) and the project RECONNECT (PTDC/ MAR/64627/2006). The authors acknowledge all researchers and technicians from IMAR-CIC that were indirectly involved in data acquisition through field and/or laboratory work and Ricardo Lopes for his help with some figures.

\section{References}

Arhonditsis, G.B., Brett, M.T., 2005. Eutrophication model for lake Washington (USA): part II - model calibration and system dynamics analysis. Ecological Modelling 187, 179-200.

Astill, H., Lavery, P.S., 2001. The dynamics of unattached benthic macroalgal accumulations in the swan-canning estuary. Hydrological Processes 15 (13), 2387-2399.

Beer, S., Shragge, B., 1987. Photosynthetic carbon metabolism in Enteromorpha compressa (Chlorophyta). Journal of Phycology 23, $580-584$.

Bendoricchio, G., Coffaro, G., Di Luzio, M., 1993. Modelling the photosynthetic efficiency for Ulva rigida growth. Ecological Modelling 67, 221-232.

Bischof, K., Gómez, I., Molis, M., Hanelt, D., Karsten, U., Lüder, U., Roleda, M.Y., Zacher, K., Wiencke, C., 2006. Ultraviolet radiation shapes seaweed communities. Reviews in Environmental Science and Biotechnology 5 (2-3), 141-166.

Boyer, K.E., Fong, P., 2005. Macroalgal-mediated transfers of water column nitrogen to intertidal sediments and salt marsh plants. Journal of Experimental Marine Biology and Ecology 321, 59-69.

Bricker, S.B., Ferreira, J.G., Simas, T., 2003. An integrated methodology for assessment of estuarine trophic status. Ecological Modelling 169, $39-60$.
Cardoso, P.G., Pardal, M.A., Lillebø, A.I., Ferreira, S.M., Marques, J.C., Raffaelli, D., 2004. Dynamic changes of seagrass assemblages under eutrophication and implications for recovery. Journal of Experimental Marine Biology and Ecology 302, 233-248.

Chapman, A.R.O., 1986. Population and community ecology of seaweeds. Advances in Marine Ecology 23, 1-161.

EPA - Environmental Protection Agency, USA, 1985. Rates, constants, and kinetics. Formulations in Surface Water Quality Modelling, second ed., 455pp.

EPA. <http://www.epa.gov/climatechange/science/futuretc.html>.

Flavier, A.B., Ziyigmark, R.G., 1993. Macroalgal recruitment in a high marsh creek of north inlet estuary, South Carolina. Journal of Phycology 29 (1), 2-8.

Fletcher, R.L., 1989. A bioassay technique using the marine fouling green alga Enteromorpha. International Biodeterioration 25, 407-422.

Grall, J., Chauvoud, L., 2002. Marine eutrophication and benthos: the need for new approaches and concepts. Global Change Biology 8, 813830.

Häder, D.P., Lebert, M., Jiménez, C., Salles, S., Aguilera, J., FloresMoya, A., Mercado, J., Viñegla, B., Figueroa, F.L., 1999. Pulse amplitude modulated fluorescence in the green macrophytes, Codium adherens, Enteromorpha muscoides, Ulva gigantea and Ulva rigida, from the Atlantic coast of Southern Spain. Environmental and Experimental Botany 41, 247-255.

Hein, M., Pedersen, M.F., Sand-Jensen, K., 1995. Size-dependent nitrogen uptake in micro- and macroalgae. Marine Ecology Progress Series 118, $247-253$.

Hoffmann, A.J., Camus, P., 1989. Sinking rates and viability of spores from benthic algae in central Chile. Journal of Experimental Marine Biology and Ecology 126, 281-291.

Huovinen, P.S., Oikari, A.O., Soimasuo, M.R., Cherr, G.N., 2000. Impact of UV radiation on the early development of the giant kelp (Macrocystis pyrifera) gametophytes. Photochemistry and Photobiology 72 (3), 308-313.

IPCC, 2007. Climate change 2007: the physical science basis. In: Solomon, S., Qin, D., Manning, M. (Eds.), Contribution of Working Group I to the Fourth Assessment Report of the Intergovernmental Panel on Climate Change.

Jørgensen, S.E., 1994. Fundamentals of Ecological Modelling, second ed. Elsevier, p. 628.

Kamer, K., Fong, P., 2001. Nitrogen enrichment ameliorates the negative effects of reduced salinity on the green macroalga Enteromorpha intestinalis. Marine Ecology Progress Series 218, 88-93.

Kim, K.Y., Lee, I.K., 1996. The germlin growth of Enteromorpha intestinalis (Chlorophyta) in laboratory culture under different combinations of irradiance and salinity and temperature and salinity. Phycologia 35 (4), 327-331.

Lillebø, A.I., Neto, J.M., Martins, I., Verdelhos, T., Leston, S., Cardoso, P.G., Ferreira, S.M., Marques, J.C., Pardal, M.A., 2005. Management of a shallow temperate estuary to control eutrophication: the effect of hydrodynamics on the system's loading. Estuarine Coastal and Shelf Science 65, 697-707.

Lotze, H.K., Worm, B., 2000. Variable and complementary effects of herbivores on different life stages of bloom-forming macroalgae. Marine Ecology Progress Series 200, 167-175.

Lotze, H.K., Schramm, W., Schories, D., Worm, B., 1999. Control of macroalgal blooms at early developmental stages: Pilayella littoralis versus Enteromorpha spp. Oecologia 119, 46-54.

Martins, I., Marques, J.C., 2002. A model for the growth of opportunistic macroalgae (Enteromorpha sp.) in tidal estuaries. Estuarine Coastal and Shelf Science 55 (2), 247-257.

Martins, I., Oliveira, J.M., Flindt, M.R., Marques, J.C., 1999. The effect of salinity on the growth rate of the macroalgae Enteromorpha intestinalis (Chlorophyta) in the Mondego estuary (west Portugal). Acta Oecologica 20, 259-265.

Martins, I., Pardal, M.A., Lillebø, A.I., Flindt, M.R., Marques, J.C., 2001. Hydrodynamics as a major factor controlling the occurrence of green macroalgal blooms in a eutrophic estuary: a case study on the 
influence of precipitation and river management. Estuarine Coastal and Shelf Science 52, 165-177.

Martins, I., Lopes, R.J., Lillebø, A.I., Neto, J.M., Pardal, M.A., Ferreira, J.G., Marques, J.C., 2007. Significant variations in the productivity of green macroalgae in a mesotidal estuary: implications to the nutrient loading of the system and the adjacent coastal area. Marine Pollution Bulletin 54, 678-690.

Matta, J.L., Chapman, D.J., 1995. Effects of light, temperature and desiccation on the net emersed productivity of the intertidal macroalga Colpomenia peregrina Sauv. (Hamel). Journal of Experimental Marine Biology and Ecology 189, 13-27.

Neto, J.M., Flindt, M.R., Marques, J.C., Pardal, M.A., 2008. Modelling nutrient mass balance in a temperate meso-tidal estuary: Implications for management. Estuarine, Coastal and Shelf Science 76, 175-185.

Niesenbaum, R.A., 1988. The ecology of sporulation by the macroalga Ulva lactuca L. (Chlorophyceae). Aquatic Botany 32, 155-166.

Norkko, J., Bonsdorff, E., Norkko, A., 2000. Drifting algal mats as an alternative habitat for benthic invertebrates: species-specific responses to a transient resource. J. Exp. Mar. Ecol. 248, 79-104.

Overpeck, J.T., Cole, J.E., 2006. Abrupt change in earth's climate system. Annual Review of Environmental and Resources 31, 1-31.

Pedersen, M.F., Borum, J., 1996. Nutrient control of algal growth in estuarine waters. Nutrient limitation and the importance of nitrogen requirements and nitrogen storage among phytoplankton and species of macrolagae. Marine Ecology Press Series 142, 261-272.

Poole, L.J., Raven, J.A., 1997. The biology of Enteromorpha. Progress in Phycological Research 12, 1-147.

Raffaelli, D.G., Raven, J.A., Poole, L.J., 1998. Ecological impact of green macroalgal blooms. Oceanography and Marine Biology: An Annual Review 36, 97-125.

Raven, J.A., Taylor, R., 2003. Macroalgal growth in nutrient-enriched estuaries: a biogeochemical and evolutionary perspective. Water, Air and Soil Pollution 3, 7-26.

Santelices, B., Hoffmann, A.J., Aedo, D., Bobadilla, M., Otaíza, R., 1995. A bank of microscopic forms on disturbed boulders and stones in tide pools. Marine Ecological Progress Series 129, 215-228.

Schories, D., 1995. Sporulation of Enteromorpha spp. (Chlorophyta) and overwintering of spores in sediments of the Wadden Sea, Island Sylt, North Sea. Netherlands Journal of Aquatic Ecology 29 (3-4), 341-347.

Schories, D., Reise, K., 1993. Germination anchorage of Enteromorpha spp. in sediments of the Wadden Sea. Helgoländer Meeresunters 47, 275-285.
Schramm, W., 1999. Factors influencing seaweed responses to eutrophication: some results from EU-project EUMAC. Journal of Applied Phycology 11, 69-78.

Shellem, B.H., Josselyn, M.N., 1982. Physiological ecology of Enteromorpha clathrata (Roth) Grev. on a salt marsh mudflat. Botanica Marina $25,541-549$.

Sousa, A.I., Martins, I., Lillebø, A.I., Flindt, M.R., Pardal, M.A., 2007. Influence of salinity, nutrients and light on the germination and growth of Enteromorpha sp. spores. Journal of Experimental Marine Biology and Ecology 341, 142-150.

Sousa, A.I., Martins, I., Flindt, M.R., Pardal, M.A., submitted for publication. Variation of spore biomass of opportunistic algae (Enteromorpha sp., Chlorophyta) in a temperate eutrophic estuary: The importance of light, temperature and hydrodynamics.

Stibal, M., Elster, J., Šabacká, M., Kaštovská, K., 2007. Seasonal and diel changes in photosynthetic activity of the snow alga Chlamydomonas nivalis (Chlorophyceae) from Svalbard determined by pulse amplitude modulation fluorometry. FEMS Microbiology Ecology 59 (2), 265 273.

Valiela, I., McClelland, J., Hauxwell, J., Behr, P.J., Hersh, D., Foreman, K., 1997. Macroalgal blooms in shallow estuaries: controls and ecophysiological and ecosystem consequences. Limnology and Oceanography 42 (5), 1105-1118.

Villares, R., Carballeira, A., 2003. Seasonal variation in the concentration of nutrients in two green macroalgae and nutrient levels in sediments in the Rias Baixas (NW Spain). Estuarine, Coastal and Shelf Science 58, 887-900.

Wiencke, C., Gómezl, I., Pakker, H., Flores-Moya, A., Altarmirano, M., Hanelt, D., Bischof, K., Figueroa, F., 2000. Impact of UV-radiation on viability, photosynthetic characteristics and DNA of brown algal zoospores: implications for depth zonation. Marine Ecology Press Series 197, 217-229.

Worm, B., Chapman, A.R.O., 1998. Relative effects of elevated grazing pressure and competition by a red algal turf on two post-settlement stages of Fucus evanescens C. Ag. Journal of Experimental Marine Biology and Ecology 220, 247-268.

Worm, B., Lotze, H.K., 2006. Effects of eutrophication, grazing, and algal blooms on rocky shores. Limnology and Oceanography 51, 569-579.

Worm, B., Lotze, H.K., Sommer, U., 2001. Algal propagule banks modify competition, consumer and resource control on Baltic rocky shores. Oecologia 128, 281-293. 